Practice in TESOL 
To Síofra and Tiernan, who always remind me of the important things in life. 


\section{Practice in TESOL}

Fiona Farr

EDINBURGH

University Press 
(c) Fiona Farr, 2015

(C) the chapters their several authors, 2015

Edinburgh University Press Ltd

The Tun - Holyrood Road

12(2f) Jackson's Entry

Edinburgh EH8 8PJ

www.euppublishing.com

Typeset in 10/12 Minion by

Servis Filmsetting Ltd, Stockport, Cheshire,

and printed and bound in Great Britain by

CPI Group (UK) Ltd, Croydon CR0 4YY

A CIP record for this book is available from the British Library

ISBN 9780748645534 (hardback)

ISBN 9780748645541 (webready PDF)

ISBN 9780748645527 (paperback)

ISBN 9780748696420 (epub)

The right of Fiona Farr to be identified as the author of this work has been asserted in accordance with the Copyright, Designs and Patents Act 1988, and the Copyright and Related Rights Regulations 2003 (SI No. 2498). 